\title{
SUSTAINED LONG-TERM IMPROVEMENT WITH CLOZAPINE IN SCHIZOPHRENIA
}

\author{
RICARDO DE OLIVEIRA-SOUZA*, ROGÉRIO PAYSANO MARROCOS **, \\ WAGNER MARTIGNONI DE FIGUEIREDO***
}

SUMMARY - The present paper reports the long-term use of clozapine in a prospective sample of $46 \mathrm{chronic}$ schizophrenics. In six months, 21 subjects had been excluded for a number of reasons. In four of them the reasons for exclusion were related to lack of response or adverse effects. The median daily clozapine dose was $400 \mathrm{mg}$ in the remaining 25 patients. As a whole, there were remarkable improvements in core dimensions of psychopathology, global cognitive status, and level of functioning. We confirmed that clozapine is effective in a subgroup of schizophrenics with the severest forms of the disease. If tolerated after the first few months it leads to progressive gains in several domains of behavior. Clozapine should be tried in every patient with schizophrenia in whom positive symptoms, disorganization, or bizarre behavior are a matter of incapacitation despite efforts to keep them under control with other drugs.

KEY WORDS: clozapine, schizophrenia, psychosis, psychopathology.

\section{Clozapina na esquizofrenia grave: melhora duradoura e sustentada}

RESUMO - O presente estudo, prospectivo, relata o uso de longo-prazo da clozapina em 46 esquizofrênicos graves, com mais de cinco anos de doença. Com seis meses de uso da droga, 21 indivíduos haviam sido excluídos por diversas razões. Em quatro, a exclusão se deveu a efeitos adversos ou ausência de resposta. A dose mediana de clozapina foi de $400 \mathrm{mg}$ nos demais 25 pacientes. No todo, observamos melhora em dimensões de psicopatologia, estado cognitivo global, e nível funcional. Concluímos que a clozapina é eficaz em um subgrupo de esquizofrênicos com formas graves da doença. Se tolerada depois dos primeiros meses, produz benefícios progressivos em diversos domínios do comportamento. Clozapina deve ser tentada em todo paciente com esquizofrenia incapacitado por sintomas positivos, desorganização, e/ou comportamentos bizarros, que persistem a despeito de esforços para mantê-los sob controle com outras drogas.

PALAVRAS-CHAVE: clozapina, esquizofrenia, psicose, psicopatologia.

Clozapine is an antipsychotic drug with negligible neuroleptic effects ${ }^{1,2}$. It has been increasingly used in patients with schizophrenia who are either intolerant or refractory to classical neuroleptics ${ }^{3}$. There are only a few studies of clozapine in Brazilian patients. Abreu et al. ${ }^{4}$ observed improvements of up to fifty percent in the Brief Psychiatric Rating Scale (BPRS) and the Positive and Negative Syndrome Scale (PANSS) in eight schizophrenics after 18 weeks of treatment. Shirakawa and Chaves ${ }^{5}$ found a decrease of PANSS scores in ten patients after clozapine. Despite the undeniable response of psychotic symptoms to the drug, its effects on primary negative and cognitive symptoms is still debated, as well as to what extent it improves the ability to handle the affairs of daily life $\mathrm{e}^{6,7}$.

In the present study we investigated the impact of the long-term treatment with clozapine on patients with severe schizophrenia using the Mini-Mental State Exam (MMSE), BPRS, and the DSM-IV scale for the assessment of global functioning (GAF).

*Serviço de Clínica Médica C (Professor Omar da Rosa Santos), Hospital Gaffrée e Guinle, Universidade do Rio de Janeiro; **Instituto Philippe Pinel, DINSAM - RJ; ***Serviço de Clínica Médica C (Professor Omar da Rosa Santos), Hospital Gaffrée e Guinle e Universidade Federal Fluminense. Aceite: 27-outubro-1998.

Dr. Ricardo de Oliveira - Rua General Belford 226 - 20961-000 Rio de Janeiro RJ - Brasil. 


\section{METHODS}

Forty-six patients with severe schizophrenia entered the study. By "severe" we understand "difficult-totreat". The reasons for this are numerous, ranging from noncompliance to drug nonresponsiveness. Twenty-one patients were excluded for several reasons. In particular, three did not respond to clozapine and in two it had to be discontinued because of adverse effects. Thus, $45 \%$ of patients with severe schizophrenia are still left with severe disability. The remaining twenty-five have been followed for the past three years as part of a prospective open-label study on the effects of atypical neuroleptics at the Instituto Philippe Pinel (IPP), a public hospital for the mentally ill which belongs to the Brazilian Ministry of Health. All had a DSM-IV diagnosis of schizophrenia ${ }^{8}$ and had been ill for at least five years (Md 14 years).

There were 6 females and 19 males with ages ranging from 30 to 52 years (Md 35 years). They have been followed as outpatients for 7 to 29 months (Md 19 months). None had ever been clinically stable after they became ill. By December 1997, when the present data were analysed, most patients had reached a stable daily dose of clozapine ranging from 200 to $700 \mathrm{mg}$ (Md $400 \mathrm{mg}$ ).

We selected from the larger study protocol the MMSE${ }^{9}$, the Hillside version of the $\mathrm{BPRS}^{10}$, and the $\mathrm{GAF}^{8}$ as measures of cognition, psychopathology, and level of functioning, respectively, for we were interested in the global effects. Percent improvement for each index was as follows: (pre-clozapine median - post-clozapine median / pre-clozapine median) x 100. The effects of clozapine on negative, positive, anxiety-depression, and hostility-aggressiveness dimensions of the BPRS ${ }^{11}$ was analysed with the Wilcoxon test, one-tailed ${ }^{12}$.

\section{RESULTS}

Most patients who showed good tolerance and compliance for a minimum of six months experienced obvious clinical improvement. The changes were gradual in onset, but even the most aggressive, psychotic and disorganized found some relief of symptoms. They became clinically stable and let themselves be handled more easily by relatives and caregivers. Two patients who developed seizures and obsessive-compulsive disorder responded favorably to valproate and sertraline, respectively. The pre-clozapine diagnostic subtypes were catatonic $(\mathrm{N}=8)$, paranoid $(\mathrm{N}=8)$, disorganized $(\mathrm{N}=8)$ and undifferentiated $(\mathrm{N}=1)$. Following clinical improvement, there was a change in the diagnoses of 13 patients to the residual subtype $(\mathrm{p}<0.0001$; McNemar test, twotailed). Associated diagnoses included depression $(\mathrm{N}=7)$, obsessive-compulsive disorder $(\mathrm{N}=3)$, severe generalized dystonia $(\mathrm{N}=1)$, severe generalized tardive stereotypy $(\mathrm{N}=1)$, and drug dependence $(\mathrm{N}=1)$.

The GAF median increased from 25 to $40(\mathrm{p}=0.0001)$. The GAF scores increased in 21 patients, did not change in four and did not decrease in any. Before treatment no patient had a GAF higher than 50 and ten had scores below 25 . After treatment, five patients reached scores above 50 and none scored below 25. The median of the BPRS total score decreased from 54 to 35 ( $\mathrm{p}=$ 0. 0001). The median of the negative symptom cluster decreased from 10 to 9 ( $p=0.002)$, of the positive symptom cluster from 13 to $8(\mathrm{p}=0.0005)$, of the anxiety-depression cluster from 12 to 6 (p $=0.0001)$, and of the hostility-aggressive cluster from 8 to $5(\mathrm{p}=0.0005)$. Pre-clozapine data from four patients who could not cooperate were discarded. The MMSE median of the remaining 21 patients increased from 27 to $29(\mathrm{p}=0.0025)$.

Nine patients also received a selective serotonin reuptake inhibitor (SSRI) for depression and OCD. To see whether the addition of an SSRI to the core regimen had any effect on the clinical changes, we compared the group with clozapine only with the group receiving clozapine and a SSRI (the "plus" group) with the Kolmogorov-Smirnov test for two samples, two-tailed. There was no significant difference for the GAF, MMSE, total BPRS, and the BPRS positive, negative, anxietydepression, and hostility scores. Finally, there was an effect favoring the "plus" group regarding the change in subtype diagnoses (McNemar test, $\mathrm{p}=0.016$ ). The following is an illustration of commonly observed patterns of response. 


\section{Low responder}

A 22-year-old technician became restless at work, stating that an angel wanted to kill him. He went home and locked himself indoors. He eventually became mute and withdrawn, without concern for self-care. Several months later, he accepted going to a doctor. He was prescribed neuroleptics and improved a little. Since then, he has lived on his sister and alternated periods of psychomotor retardation with aimless walking. When we first saw him five years later his communicative abilities were kept to a minimum. He was oriented to time and place, and followed verbal and gestural commands. He scored 27 on the MMSE, 25 on the GAF and 56 on the BPRS. He did not show any initiative and would spend several minutes in awkward grimaces, vocalizations and hand gestures which occurred intermittently as part of senseless behavioral sequences. He was on a stable regimen of thioridazine, $300 \mathrm{mg} / \mathrm{day}$. He was given a diagnosis of catatonic schizophrenia and switched to clozapine. Twenty-nine months later he had reached a daily dose of $400 \mathrm{mg}$. By then, his GAF was still 25, his MMSE was 26 and the BPRS total score dropped to 45.

Comment: This is an example of clozapine-resistant schziophrenia in a deteriorated patient. There was nothing in his clinical features which might have foretold a poor response to neuroleptics. The cases below are similar in many respects, but they otherwise responded favorably.

\section{Intermediate responder}

This 51-year-old man began to do repetitive acts and to avoid social contact by the age of 13 . He had terrifying visions and heard threatening voices. He behaved aggressively towards his relatives and attempted to kill his younger sister. His illness followed a devastating downhill course, and by 18 -years-old he had already become as abulic and mute as he is today, a state occasionaly broken by spells of blind destructiveness. He was given several neuroleptics with frequent drug-induced parkinsonism. When first seen three years ago, he would spend most of his days motionless in bed. He followed verbal commands very slowly, had waxy flexibility, catalepsy, and automatic obedience. He received a subtype diagnosis of catatonia. A CT scan showed ventricular enlargement and atrophy of the frontal lobes. Prior to clozapine he scored 10 on the GAF, 112 on the BPRS, and 23 on the MMSE. He gradually became more interested in his surroundings and no longer displayed aggressive outbursts. He now enjoys going to the seashore with his sister to look at people on the beach. His diagnostic subtype did not change and his indexes are as follows: GAF 25, BPRS 59, MMSE 29. His negative symptom score decreased from 20 to 14 .

Comment: The appearance of this patient, a kraepelinian schizophrenic ${ }^{13}$, did not change much. However, he became socially better adjusted and the quality of life of those who live with him visibly improved.

\section{High responder}

This 35-year-old man was brought to the emergency room by his mother in 1995 because of psychomotor agitation, paranoid delusions, and blunted behavioral responsivity. He had been ill for 20 years, with a history of cocaine, marijuana and alcohol abuse and several therapeutic failures with multiple neuroleptic regimens and hospital admissions. When first seen, he was depressed, suspicious, and unable to care for himself. He displayed a variety of grimaces and aimless gestures, and rarely complied with the examiner. He would spend the whole day in bed motionless. He was given the diagnoses of catatonic schizophrenia, depression, and drug dependence. While in hospital, he repetitively blamed himself for having murdered a patient. He set fire on his bed and attempted suicide a couple of times. He was given a trial of ECT and dramatically improved from depression, but remained psychotic and withdrawn. He gradually improved after clozapine and sertraline. Two years later, he entered the university and the Anonimous Narcotics, and enjoyed playing soccer. His interpersonal skills improved and he has a girlfriend. Rarely, he still looks suspicious and regrets having murdered a man. 


\section{DISCUSSION}

Before witnessing the effects of clozapine, we were concerned whether the regional profile of our sample would interfere in any decisive way with the ethnopharmacological responses to the drug. The patients were representative of a segment of the Rio de Janeiro population which includes a major contingent of families of low income living in loosely structured environments. Thus, one important aspect of our findings was the fact that, at least in this small sample, clozapine seemed to work as it reportedly does in the northern hemisphere and in comparable dose ranges.

Our findings are in accordance with our main selection criterion, which was based on longterm compliance. Thus, most patients who adhered to clozapine in the long-term experienced major benefits. Such effects were clinically obvious and could be measured by scales simple enough to be used routinely. The most dramatic changes were on a functional measure, the GAF, an effect associated with a comparable improvement in psychopathology. Following clozapine, there was a progressive and sustained improvement in the GAF (60\%), BPRS (36\%) and MMSE (7\%). The negative, positive, anxiety-depression, and hostility-aggressive clusters of the BPRS showed improvements of $10 \%$, $38 \%, 50 \%$, and $37 \%$, respectively. The change of diagnostic subtype in nearly half of the patients illustrates the longitudinal unstability of schizophrenia subtypes.

The issue of cognitive improvement following clozapine has been much debated. Goldberg et al. ${ }^{14}$ found no significant changes on tests of memory, performance, executive functions and complex visual perception in 15 patients who had been using a classic neuroleptic. Others, however, reached diverging conclusions. Lee et al. ${ }^{15}$, for example, showed that clozapine improved verbal fluency and attention, a finding that may be explained by differences in experimental design, sample size, and composition of the neuropsychological battery. In our patients clozapine exerted a small effect on global cognition as assessed by the MMSE. The fact that neuroleptics do not typically modify tests such as the $\mathrm{MMSE}^{16}$ suggests that the increase in scores was a legitimate effect, and not merely an effect of the withdrawal of the neuroleptic which preceded it.

This investigation suffers from a number of limitations. Since all patients were on a neuroleptic immediately before switching to clozapine, we do not know how much improvement should be credited to the remission of secondary negative symptoms caused by the previous drug regimen. Moreover, our assessments were not blind, nor did we control our results to see how a comparable group of patients treated with a conventional antipsychotic would fare on the same measures in an equivalent time frame. Nevertheless, despite the well-known drawbacks of open-label studies, the contrast between the past and current life of our patients indicates that clozapine played a decisive role in their clinical improvement and stabilization. We conclude that clozapine is underemployed in our milieu because of unjustified concerns regarding its profile of adverse effects ${ }^{17}$. As happened with our patients, many others may have been exposed to high levels of neuroleptics for years without being given the opportunity of a full clozapine trial.

Acknowledgements - We are indebted to Naná Sette Câmara and Prof. Alice Rosa for the support to the Neuropsychiatric Unit at the IPP. This work could not have been done without the administrative competence of Dr. Ricardo Peret, Director of IPP, who foresaw the value of clozapine when it was still taken as a "dangerous drug". We are also indebted to Dr. Herbert Y. Meltzer for insightful comments on the manuscript.

\section{REFERENCES}

1. Honigfeld G: The Clozapine National Registry System: forty years of risk management. J Clin Psychiatry Monograph 1996;14:29-32.

2. Kane J, Honigfeld G, Singer J, Meltzer HY. Clozapine for the treatment-resistant schizophrenic: a double-blind comparison with chlorpromazine. Arch Gen Psychiatry 1988;45:789-796.

3. Meltzer HY: Penetrating the secrets of schizophrenia: the history of clozapine therapy. Sandoz Bull 1994;30:16-22.

4. Abreu PSB, Schestatsky S, Lobato MI, Baron ALD, Souza S, Kaefer H. Clozapine in patients with schizophrenia: changes in psychopathology (Port). J Bras Psiquiatria 1995;44:59-62. 
5. Shirakawa I, Chaves AC. One-year experience with clozapine in the treatment of chronic schizophrenic patients (Port). J Bras Psiquiatria 1996;45:23-26.

6. Meltzer HY, Burnett S, Bastani B, Ramirez LF: Effects of six months of clozapine treatment on the quality of life of chronic schizophrenia patients. Hosp Comm Psychiatry 1990;41:892-897.

7. Meltzer HY, Thompson PA, Lee MA, Ranjan R: Neuropsychologic deficits in schizophrenia. relation to social function and effect of antipsychotic drug treatment. Neuropsychopharmacology 1996;14(Suppl 3):27-33.

8. American Psychiatric Association. Diagnostic and statistic manual of mental disorders. 4.Ed. (DSM-IV). Washington, DC: American Psychiatric Association 1994.

9. Folstein MF, Folstein SE, McHugh PR. "Mini-Mental State": a practical method for grading the cognitive state of patients for the clinician. J Psychiat Res 1975;12:189-198.

10. Woerner MG, Mannuzza S, Kane JM: Anchoring the BPRS: an aid to improved reliability. Psychopharmacol Bull 1988;24:112-117.

11. Hedlund JL, Vieweg BW. The brief psychiatric rating scale (BPRS): a comprehensive review. J Oper Psychiat 1980;11:48-65.

12. Siegel S. Nonparametric statistics for the behavioral sciences. New York: McGraw-Hill, 1956.

13. Keefe SER, Mohs RC, Losonczy MF, et al. Characteristics of very poor outcome schizophrenia. Am J Psychiatry, 1987;144:889-895.

14. Goldberg TE, Greenberg RD, Griffin SJ, et al. The effect of clozapine on cognition and psychiatric symptoms in patients with schizophrenia. Br J Psychiatry 1993;162:43-48.

15. Lee MA, Thompson PA, Meltzer HY. Effects of clozapine on cognitive function in schizophrenia. J Clin Psychiatry 1994;55(Suppl B):82-87.

16. King DJ. The effect of neuroleptics on cognitive and psychomotor function. Br J Psychiatry 1990;157:799-811.

17. Rosenheck R, Cramer J, Xu W, et al. A comparison of clozapine and haloperidol in hospitalized patients with refractory schizophrenia. N Engl J Med 1997;337:809-815. 